Case Report

\title{
Primary Pleomorphic Liposarcoma of Liver: A Case Report and Review of the Literature
}

\author{
P. R. Thippeswamy Naik, Prem Kumar, and P. Vinod Kumar \\ Department of General Surgery, Victoria Hospital, Bangalore Medical College \& Research Institute, Bangalore, \\ Karnataka 560002, India \\ Correspondence should be addressed to P. Vinod Kumar; vinodkumarbmc144@gmail.com
}

Received 21 November 2012; Accepted 12 December 2012

Academic Editors: H. Komatsu and N. Snyder

Copyright ( 2013 P. R. Thippeswamy Naik et al. This is an open access article distributed under the Creative Commons Attribution License, which permits unrestricted use, distribution, and reproduction in any medium, provided the original work is properly cited.

Primary liver liposarcoma is a rare disease. The knowledge of the clinical course, management, and prognosis of primary liver liposarcoma are all limited because of its rarity. Twelve cases of primary liposarcoma of the liver have been previously reported. We present the thirteenth case, which occurred in an adult male patient. A 42-year-old male patient came to our outpatient department with complaints of pain abdomen, mass per abdomen, and weight loss. Ultrasonography showed a mass arising from the the left lobe of liver. CT abdomen showed a heterogenous enhancing mass from left lobe of liver with multiple cystic and necrotic areas compressing the stomach and spleen with no evidence of metastasis. Differential diagnosis included adenoma and primary malignancy. Exploratory laparotomy and resection were done. HPE was found to be pleomorphic liposarcoma of liver.

\section{Introduction}

Virchow first described a malignant tumor of fatty tissue arising in the lower extremity in 1857 [1]. Since then, liposarcomas have been identified in a number of tissue and organs, but only rarely in the liver. The most common sites are the deep soft tissue of the trunk, retroperitoneum, and the subcutaneous fat of the upper and lower extremities [2]. Liposarcoma itself constitutes about $9.8 \%$ to $18 \%$ of soft tissue sarcomas; its incidence is second only to that of Malignant Fibrous Histiocytoma (MFH) [3]. The experience in dealing with this malignant neoplasm is limited because of its rarity. Primary liposarcoma of the liver must be considered in the differential diagnosis of a hepatic mass that develops in a noncirrhotic liver in whom liver transplantation may be considered as liposarcoma is clearly an absolute contraindication for liver transplantation [4]. Hepatic resections might be efficient although prognosis is poor and recurrence is more.

Furthermore, most of the articles describing liver liposarcoma concentrate only on histopathological and imaging studies. The clinical course and prognosis of primary liver sarcoma are rarely mentioned. Hence we report a case of liposarcoma liver in detail.

\section{Case Report}

A 42-year-old male patient had history of pain abdomen which he attributed to a mass per abdomen noticed since 15 days. Pain was intermittent, dull aching variety with symptom-free intervals. He also complained of weight loss. On examination, a mass of size approximately $15 \times 10 \mathrm{~cm}$ was felt occupying the epigastrium and left hypochondrium. All the blood tests were normal. Chest $\mathrm{X}$ ray revealed elevation of left hemidiaphragm and Ultrasonography revealed a large heterogenous mass lesion of size around $18 \times 15 \mathrm{~cm}$ arising from the liver occupying the epigastrium, left hypochondrium extending up to splenic hilum. Liver function tests were normal. CT abdomen showed a large lobulated, welldefined, heterogeneously enhancing mass lesion of size $18 \times$ $14 \times 13 \mathrm{~cm}$ from the left lobe of liver with multiple cystic, necrotic areas and compressing the stomach and spleen (Figure 1). Upper GI Endoscopy showed external compression on the anterior wall of stomach.

Differential diagnosis of a primary hepatic adenoma and carcinoma was made. There were no risk factors for malignancy. AFP levels were normal. FNAC was not attempted due to risk of tumor seeding and haemorrhage. Metastatic workup 


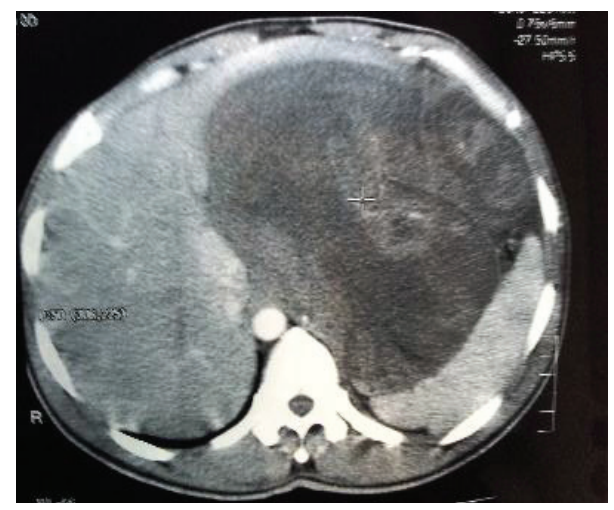

FIGURE 1: CECT Showing the huge mass from the left lobe of liver, compressing liver and spleen.

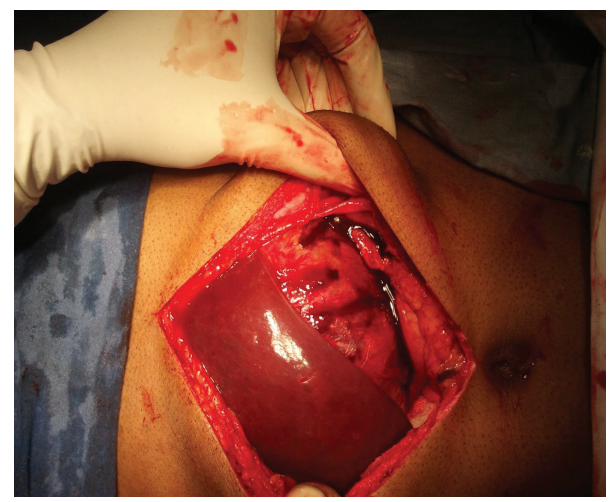

Figure 2: Liver mass seen on opening the abdomen.

was done and no metastases was identified. CT Chest, pelvis was normal. During laparotomy, mass was arising from liver (Figure 2). The left lobe of liver was thinned out because of the tumor pressure effect. The tumor was adherent to the left hemidiaphragm and the upper spleen.

En bloc resection of the tumor mass and extended left lateral hepatectomy with resection of the part of left hemi diaphragm and upper part of spleen was done. Diaphragmatic rent was closed with mesh and splenorrhaphy was done (Figure 3).

An ICD was also put in the left pleural space. Specimen was sent for histopathological department for examination. Grossly, cut section of the tumor showed a soft fleshy, friable mass with extensive foci of haemorrhage and necrosis (Figure 4).

Microscopy showed a tumor with sheets of large pleomorphic cells with vesicular hyperchromatic nuclei showing plenty of mitosis, occasional lipoblasts, and thick capsule with tumor infiltration suggestive of pleomorphic liposarcoma (Figure 5). Diaphragmatic tissue showed tumor remnants on the undersurface with focal infiltration and splenic tissue was normal with capsule showing infiltration.

Immunohistochemistry. Test result-NEGATIVE for S 100, CK, and EMA. Postoperative course was uneventful. The patient tolerated normal activity and enteral feeds. Chest tube was

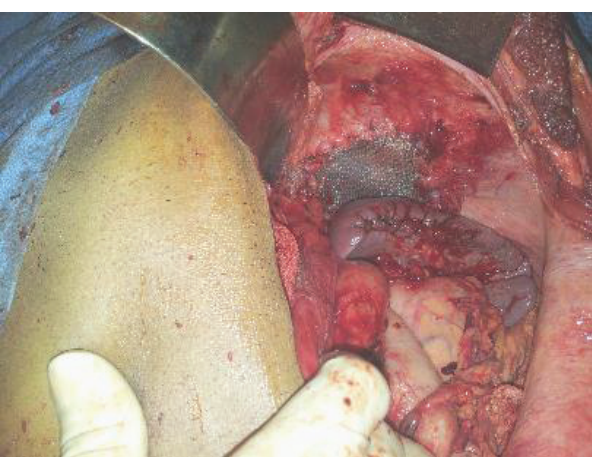

FIgURE 3: Postresection showing partially resected spleen and mesh repair of diaphragm.

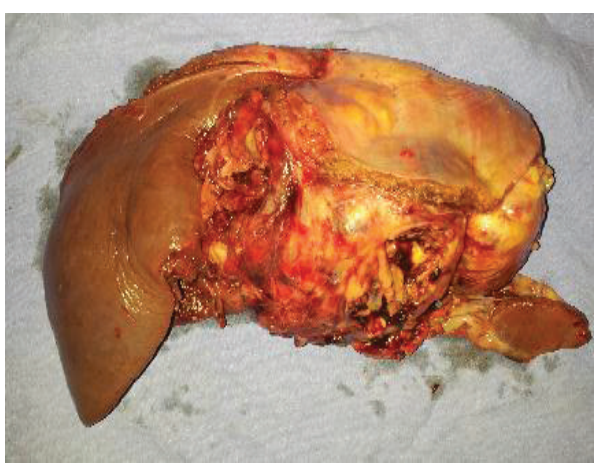

FIGURE 4: Gross specimen of tumor.

removed and discharged and he was referred to oncology department. Clinical stage: Stage III [T2b N0 M0 G3] as per AJCC staging. And hence the patient was put on adjuvant chemoradiotherapy and now is free of recurrence.

\section{Discussion}

Primary tumors arising from the liver are common. The differential diagnosis of primary hepatic mass should include Benign and Malignant tumors.

Classifications on the basis of cell origin include

(a) epithelial origin,

(b) mesenchymal origin,

(c) mixed origin,

(d) others.

Primary hepatic sarcomas are rare accounting for 1$2 \%$ of all primary malignant tumors of liver. Among these, angiosarcoma and hemangioendothelioma are most common [17]. Liposarcoma is a tumor derived from primitive cells that undergo adipose differentiation. It is largely a disease of adults, with peak incidence between 40 and 60 years age group, and it shows a slight predominance toward men [18]. When liposarcomas do occur in children, they tend to present in the second decade of life. In either event, the deep soft tissues of the extremities, particularly those of the thigh, are the most common location, accounting for more than 
$50 \%$ of liposarcomas [19]. One unique feature of liposarcoma is its tendency to occur in visceral spaces, particularly that of the retroperitoneum. Liposarcoma may occur in many other locations. About 5\% occur in head and neck and 10\% in upper extremity. Other unusual locations are axilla, vulva, peritoneal cavity, spermatic cord, and even the breast.

There have been many attempts to classify liposarcomas depending on a combination of two basic histological aspects of the tumor:

(a) the stage of the differentiation of lipoblasts, based on relative amounts of lipid in the cells and myxoid material in the extracellular spaces, and

(b) the overall degree of cellularity and cellular pleomorphism.

Primary hepatic liposarcoma is extremely rare although liposarcoma is one of the common soft tissue malignancies which occurs usually in the extremities and retroperitoneum [20]. Early diagnosis of primary liposarcoma of liver is not easy. Liver is the largest solid organ in the body, and symptoms and signs of a tumor in the liver usually go undetected unless the tumors are large. The common symptoms and signs of primary liver liposarcoma include nausea, vomiting, fever, jaundice, abdominal fullness, right upper quadrant pain, and weight loss. Most of the symptoms are usually caused by displacement or compression of nerves, vessels, biliary tract, and intestines.

Abdominal ultrasonography usually is a good tool to do preoperative screening and postoperative followup. Computed tomography is still the best tool to evaluate the resectability of liver liposarcoma before surgery. Contrast enhancement depends on the level of differentiation. Little enhancement is noted in well-differentiated liposarcomas, and more with round cell, pleomorphic, and dedifferentiated subtypes. Corresponding heterogeneity with regards to contrast enhancement is seen in Myxoid variety [21]. Other findings of liposarcoma are thick fibrous septae, nodularity and foci of hemorrhage, and necrosis. Metastatic spread of soft tissue liposarcomas is relatively common, but still liver is involved in only $10 \%$ of cases. Metastases are usually found in the brain, pleura, thyroid, pancreas, and spinal cord.

World Health Organization (WHO) Divides Primary Hepatic Liposarcomas into Four Subtypes Table 1 shows the four different WHO subtypes

(1) Myxoid liposarcoma: it is the most common type in pediatric age group. It is Intermediate grade but its round-cell variant is high grade in nature and can metastasize.

(2) Well-differentiated liposarcoma: it is the most common subtype (50\% of liposarcomas) and includes atypical lipoma. It is low grade (does not metastasize, but may recur locally). There is minimal risk of dedifferentiation.

(3) Dedifferentiated liposarcoma: it is most common with retroperitoneal lesions. High-grade sarcoma arising in association with well-differentiated liposarcoma.

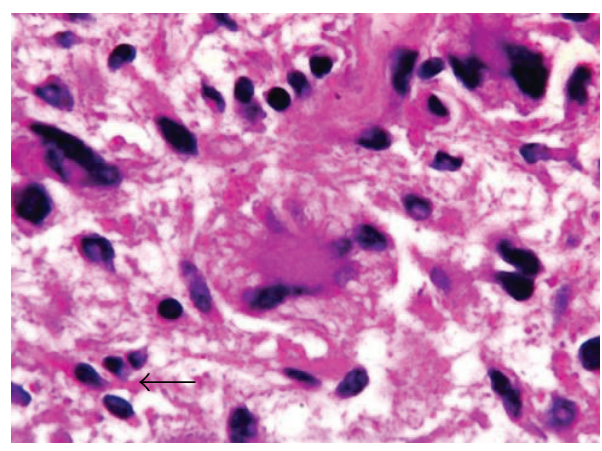

FIGURE 5: Microscopy showing large pleomorphic cells (arrow) interspersed in a loose connective tissue stroma.

(4) Pleomorphic liposarcoma: it is the rarest type (5-10\% of liposarcomas). High grade in nature and may mimic MFH or even carcinoma or melanoma. There is very high chance of local recurrence and metastasis. (Compiled from Peterson et al. 2003 [3], Dei Tos 2000 [22], Coffin 1997 [19], Enzinger and Weiss 1995 [9], and Weiss and Rao 1992 [23])

A number of cytogenetic correlations also have been made with liposarcoma. Well-differentiated liposarcomas have been associated with abnormalities derived from the q13-15 region of chromosome 12 . Such abnormalities also are found in dedifferentiated liposarcoma. Perhaps, genetic association is best characterized for myxoid liposarcoma. This represents a translocation between two chromosomes. In myxoid liposarcoma, the translocation is between chromosomes 12 and 16. The result is a gene called TLS-CHOP which is an oncogene. This particular translocation is highly specific for myxoid liposarcoma and therefore is diagnostic of this tumor [24].

Surgical curative resection with clear margins remains the mainstay of treatment except in cases of advanced liposarcoma with metastasis where palliative treatment can be given. But inspite of complete R0 resection, there is a high chance of recurrence particularly in pleomorphic variety. The role of radiotherapy is not well defined. Chemotherapy for high-grade liposarcoma has been tried with low success rates. Patient prognosis depends on histological subtype, grading, and tumor necrosis. The 5-year survival rate of patients who have undergone curative resection or radiation therapy is approximately 50\% [25].

Table 2 is a list of previously reported cases [5-16].

Ours is the 13th case involving the left lobe for which left lateral lobectomy was done with HPE showing pleomorphic liposarcoma. The patient is still on followup and is tumor free till now. Based on the previous reports, The following predictions can be drawn about primary pleomorphic liposarcoma of liver.

(a) There is higher incidence in adult females with 7 cases as opposed to 3 in male adults and 3 involving children.

(b) There is no predilection for lobar involvement with 5 cases affecting each of the right and left lobes equally. 
TABLE 1

\begin{tabular}{lccc}
\hline S1 & Tumor & Abberation & Genes involved \\
\hline (1) & Myxoid/round cell liposarcoma, & $\mathrm{t}(12 ; 16)(\mathrm{q} 13 ; \mathrm{p} 11)$ & TLS-CHOP \\
& Atypical lipomatous & Supernumerary ring & Amplification of region \\
(2) & chromosomes; giant & 12q13-15, including MDM2, \\
& liposarcoma & marker chromosomes & CDK4, HMGA2, SAS, GL1 \\
& & Supernumerary ring & Amplification of region \\
$(3)$ & Dedifferentiated liposarcoma & chromosomes; giant & CDK4, HMGA2, SAS, GL1 \\
& & marker chromosomes & UNKNOWN \\
\hline
\end{tabular}

(NCCN guidelines V.2.2009).

TABLE 2

\begin{tabular}{|c|c|c|c|c|c|c|}
\hline Sl no & Age/sex & Location & Management & Followup & WHO subtype & Source \\
\hline (1) & $22 / \mathrm{F}$ & Right lobe & $\begin{array}{c}\text { Right lobe } \\
\text { hepatectomy }\end{array}$ & Survival 46 days & - & Wolloch et al., 1973 [5] \\
\hline (2) & $86 / \mathrm{M}$ & Capsule & $\begin{array}{l}\text { Supportive } \\
\text { treatment }\end{array}$ & - & Myxoid & Kim and Reyes, 1985 [6] \\
\hline (3) & $30 / \mathrm{F}$ & Left lobe & $\begin{array}{c}\text { Left lobe } \\
\text { hepatectomy }\end{array}$ & $\begin{array}{l}\text { Tumor free for } \\
10 \text { month }\end{array}$ & Dedifferentiated & Kim et al., 1987 [7] \\
\hline$(4)$ & $02 / \mathrm{M}$ & Hilum & Autopsy & - & - & Soares et al., 1989 [8] \\
\hline (5) & $03 / \mathrm{M}$ & Hilum & - & - & Myxoid & Wright et al., 1993 [9] \\
\hline (6) & $48 / \mathrm{F}$ & Hilum & Chemotherapy & - & - & $\begin{array}{c}\text { Aribal and Berberoglu , } \\
1993[10]\end{array}$ \\
\hline (7) & $54 / \mathrm{F}$ & $\begin{array}{l}\text { Right and } \\
\text { left lobes }\end{array}$ & $\begin{array}{c}\text { Exploratory } \\
\text { laparotomy with } \\
\text { Biopsy }\end{array}$ & $\begin{array}{c}\text { Postop. bleeding } \\
\text { and death }\end{array}$ & Myxoid & Nelson et al., 2001 [11] \\
\hline$(8)$ & $14 / \mathrm{M}$ & Right lobe & $\begin{array}{c}\text { Right lobe } \\
\text { hepatectomy }\end{array}$ & - & Round cell & Lu et al., 2003 [12] \\
\hline (9) & $61 / \mathrm{F}$ & Right lobe & $\begin{array}{c}\text { Right lobe } \\
\text { hepatectomy }\end{array}$ & $\begin{array}{l}\text { Survival } 27 \\
\text { months }\end{array}$ & Myxoid & Kuo et al., 2006 [13] \\
\hline$(10)$ & $63 / \mathrm{F}$ & Left lobe & $\begin{array}{c}\text { Left lobe } \\
\text { hepatectomy }\end{array}$ & - & $\begin{array}{c}\text { Well } \\
\text { differentiated }\end{array}$ & Kim et al., 2007 [14] \\
\hline$(11)$ & $21 / \mathrm{F}$ & Right lobe & $\begin{array}{c}\text { Right lobe } \\
\text { hepatectomy }\end{array}$ & $\begin{array}{l}\text { Death } 9 \text { months } \\
\text { after surgery }\end{array}$ & - & $\begin{array}{l}\text { Nakhai and Motabar, } \\
\qquad 2007 \text { [15] }\end{array}$ \\
\hline$(12)$ & $64 / \mathrm{M}$ & Left lobe & $\begin{array}{c}\text { Left lobe } \\
\text { hepatectomy }\end{array}$ & $\begin{array}{c}\text { Tumor free for } 4 \\
\text { years }\end{array}$ & Myxoid & Lin et al., 2011 [16] \\
\hline
\end{tabular}

(c) It can present at any age ranging from 2-year baby to 86-year-old adult.

(d) Myxoid variety appears to be commonest as HPE studies have not been mentioned in all of the previous reported cases.

(e) Resection is the predominant mode of treatment as other modalities are still under evaluation.

(f) Myxoid liposarcoma carries poor prognosis.

\section{Conclusion}

Primary hepatic liposarcomas should be considered in differential diagnosis of liver tumors and computed tomography is helpful in evaluation of the tumor like any other visceral soft tissue sarcoma. Moreover, pleomorphic variety has a high metastatic potential compared to other histological variants. Neo adjuvant radiotherapy may be tried for highgrade tumors if diagnosed beforehand keeping in mind its occurrence. Although multimodality treatments combining chemoradiation have been put forward to achieve long-term survival, surgical resection still is the best means to achieve survival with other modalities serving a supplementary benefit.

\section{References}

[1] R. D. Brasfield and T. K. das Gupta, "Liposarcoma," $C A-A$ Cancer Journal for Clinicians, vol. 20, no. 1, pp. 3-9, 1970.

[2] F. M. Enzinger and D. J. Winslow, "Liposarcoma-a study of 103 cases," Virchows Archiv für Pathologische Anatomie und Physiologie und für Klinische Medizin, vol. 335, no. 4, pp. 367-388, 1962. 
[3] J. J. Peterson, M. J. Kransdorf, L. W. Bancroft, and M. I. O'Connor, "Malignant fatty tumors: classification, clinical course, imaging appearance and treatment," Skeletal Radiology, vol. 32, no. 9, pp. 493-503, 2003.

[4] R. P. DeMatteo, J. J. Lewis, D. Leung, S. S. Mudan, J. M. Woodruff, and M. F. Brennan, "Two hundred gastrointestinal stromal tumors: recurrence patterns and prognostic factors for survival," Annals of Surgery, vol. 231, no. 1, pp. 51-58, 2000.

[5] Y. Wolloch, M. Dintsman, and I. Garti, "Primary malignant tumors of the liver," Israel Journal of Medical Sciences, vol. 9, no. 1, pp. 6-11, 1973.

[6] T. W. Kim and C. V. Reyes, "Myxoid liposarcoma mimicking fluid density," Journal of Surgical Oncology, vol. 30, no. 2, pp. 80-82, 1985.

[7] Y. I. Kim, E. S. Yu, K. W. Lee, E. U. Park, and H. G. Song, "Dedifferentiated liposarcoma of the liver," Cancer, vol. 60, no. 11, pp. 2785-2790, 1987.

[8] F. A. Soares, G. A. M. Landell, L. C. Peres, M. A. Oliveira, Y. A. M. V. A. Vicente, and L. G. Tone, "Liposarcoma of hepatic hilum in childhood: Report of a case and review of the literature," Medical and Pediatric Oncology, vol. 17, no. 3, pp. 239-243, 1989.

[9] N. B. Wright, R. Skinner, R. E. J. Lee, and A. W. Craft, "Myxoid liposarcoma of the porta hepatis in childhood," Pediatric Radiology, vol. 23, no. 8, pp. 620-621, 1993.

[10] E. Aribal and L. Berberoglu, "Primary liposarcoma of the liver," American Journal of Roentgenology, vol. 161, pp. 1331-1332, 1993.

[11] V. Nelson, N. F. Fernandes, G. M. Woolf, S. A. Geller, and L. M. Petrovic, "Primary liposarcoma of the liver: a case report and review of literature," Archives of Pathology \& Laboratory Medicine, vol. 125, pp. 410-412, 2001.

[12] G. L. Lu, C. B. Hsieh, J. C. Yu, D. C. Chan, C. K. Lin et al., "Primary Liposarcoma of liver in a 14 year old child," Journal of Medical Sciences, vol. 23, no. 1, pp. 57-60, 2003.

[13] L. M. Kuo, H. S. Chou, K. M. Chan, M. C. Yu, and W. C. Lee, "A case of huge primary liposarcoma in the liver," World Journal of Gastroenterology, vol. 12, no. 7, pp. 1157-1159, 2006.

[14] J. L. Kim, J. Y. Woo, M. J. Lee et al., "Imaging findings of primary well-differentiated liposarcoma of the liver: a case report," Acta Radiologica, vol. 48, no. 10, pp. 1061-1065, 2007.

[15] B. Nakhai and A. R. Motabar, "Primary liposarcoma of the liver: a case report and review of literature," Medical Journal of the Islamic Republic of Iran, vol. 21, no. 3, pp. 167-172, 2007.

[16] Y. C. Lin, W. C. Tsai, Y. C. Liu, and C. P. Yu, "Primary liposarcoma of liver: a case report and literature review," Journal of Medical Sciences, vol. 31, no. 2, pp. 81-84, 2011.

[17] E. M. Stacey and C. Darryl, Eds., Sternberg's Diagnostic Surgical Pathology, Williams \& Wilkins, Philadelphia, Pa, USA, 4th edition, 2004.

[18] F. M. Enzinger and S. W. Weiss, Tissue Tumors, Mosby, St. Louis, Mo, USA, 3rd edition, 1995.

[19] C. M. Coffin, "Adipose and myxoid tumors," in Pediatric Soft Tissue Tumors: A Clinical, Pathological, and Therapeutic Approach, C. M. Coffin, L. P. Dehner, and P. A. O'Shea, Eds., pp. 254-276, Williams \& Wilkins, Baltimore, Md, USA, 1997.

[20] Y. Barazani, J. R. Hiatt, M. J. Tong, and R. W. Busuttil, “Chronic viral hepatitis and hepatocellular carcinoma," World Journal of Surgery, vol. 31, no. 6, pp. 1243-1248, 2007.

[21] R. Arkun, A. Memis, T. Akalin, E. E. Ustun, D. Sabah, and G. Kandiloglu, "Liposarcoma of soft tissue: MRI findings with pathologic correlation," Skeletal Radiology, vol. 26, no. 3, pp. 167-172, 1997.

[22] A. P. Dei Tos, "Liposarcoma: new entities and evolving concepts," Annals of Diagnostic Pathology, vol. 4, pp. 252-266, 2000.

[23] S. W. Weiss and V. K. Rao, "Well-differentiated liposarcoma (atypical lipoma) of deep soft tissue of the extremities, retroperitoneum, and miscellaneous sites: a follow-up study of 92 cases with analysis of the incidence of 'dedifferentiation," American Journal of Surgical Pathology, vol. 16, no. 11, pp. 1051-1058, 1992.

[24] B. P. Rubin and C. D. M. Fletcher, "The cytogenetics of lipomatous tumours," Histopathology, vol. 30, no. 6, pp. 507-511, 1997.

[25] G. Steven, R. Silverberg, and A. Delelis, Principles and Practice of Surgical Pathology and Cytopathology, Churchill Levingstone, New York, NY, USA, 3rd edition, 2004. 


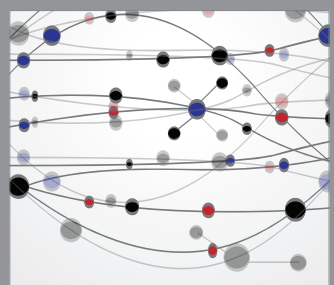

The Scientific World Journal
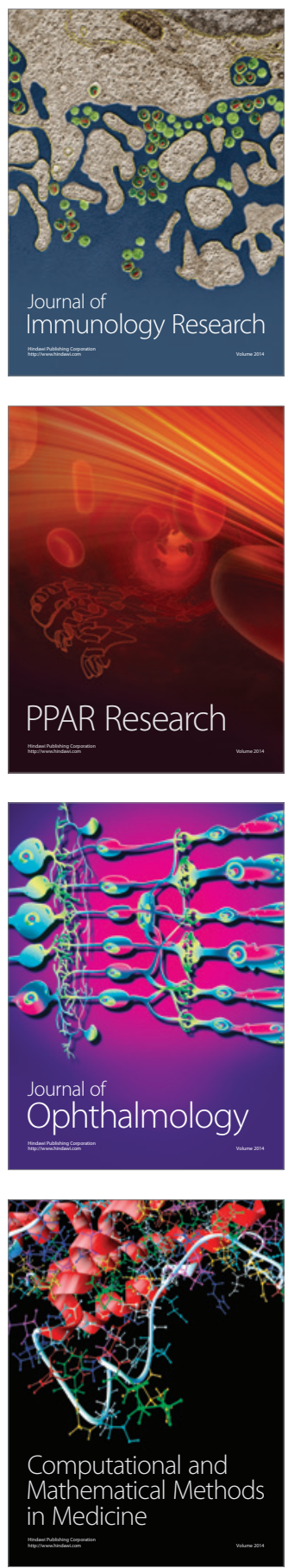

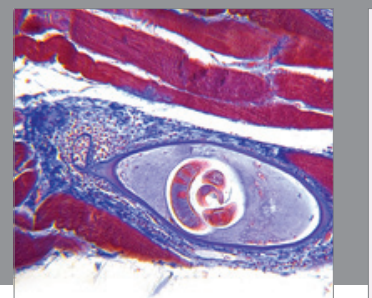

Gastroenterology

Research and Practice
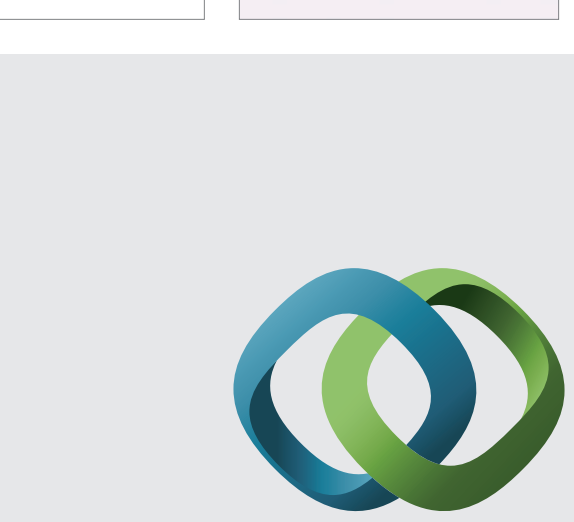

\section{Hindawi}

Submit your manuscripts at

http://www.hindawi.com
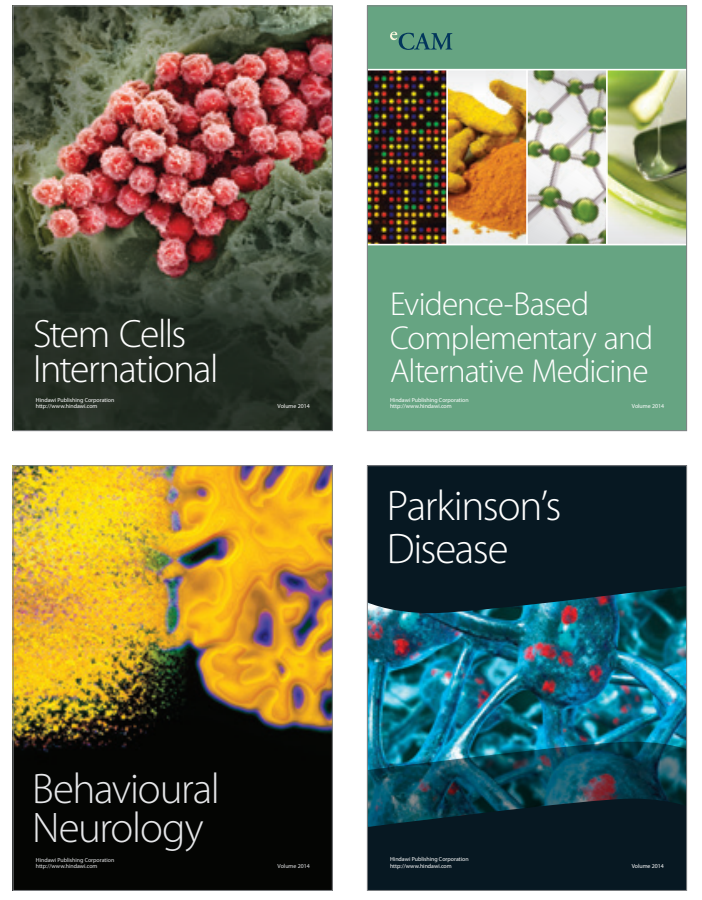
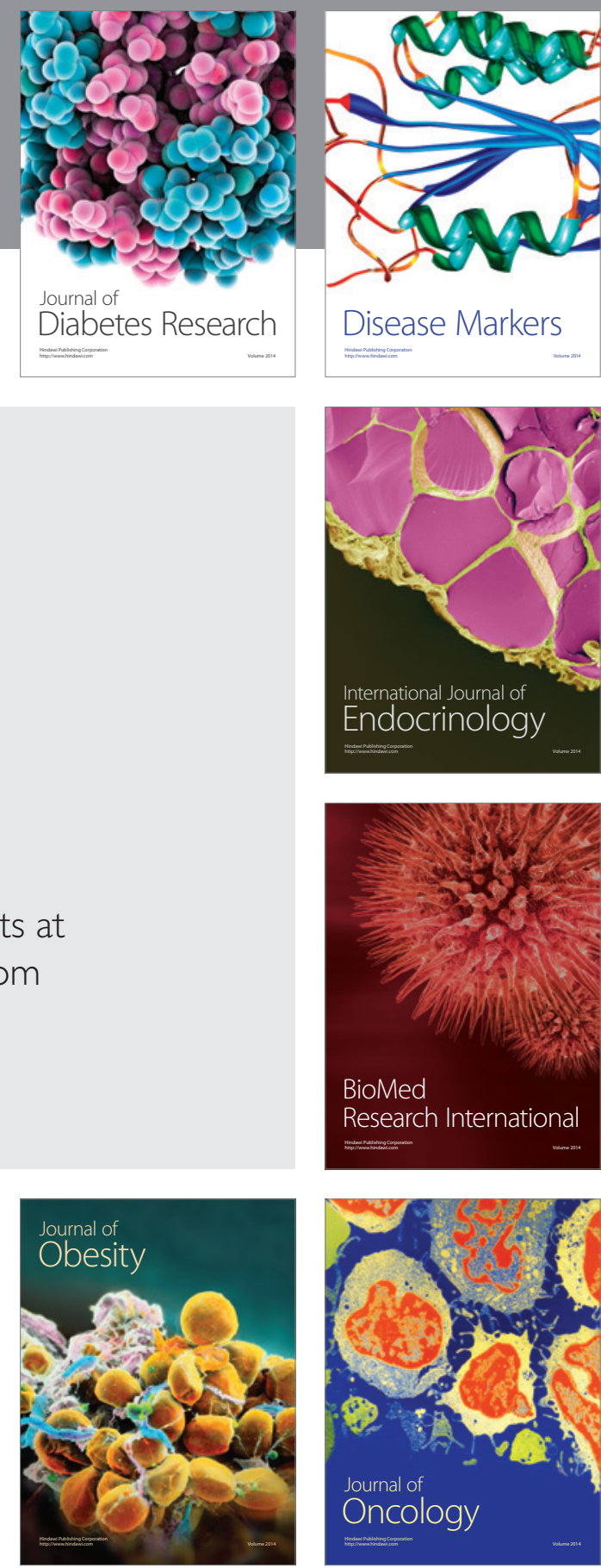

Disease Markers
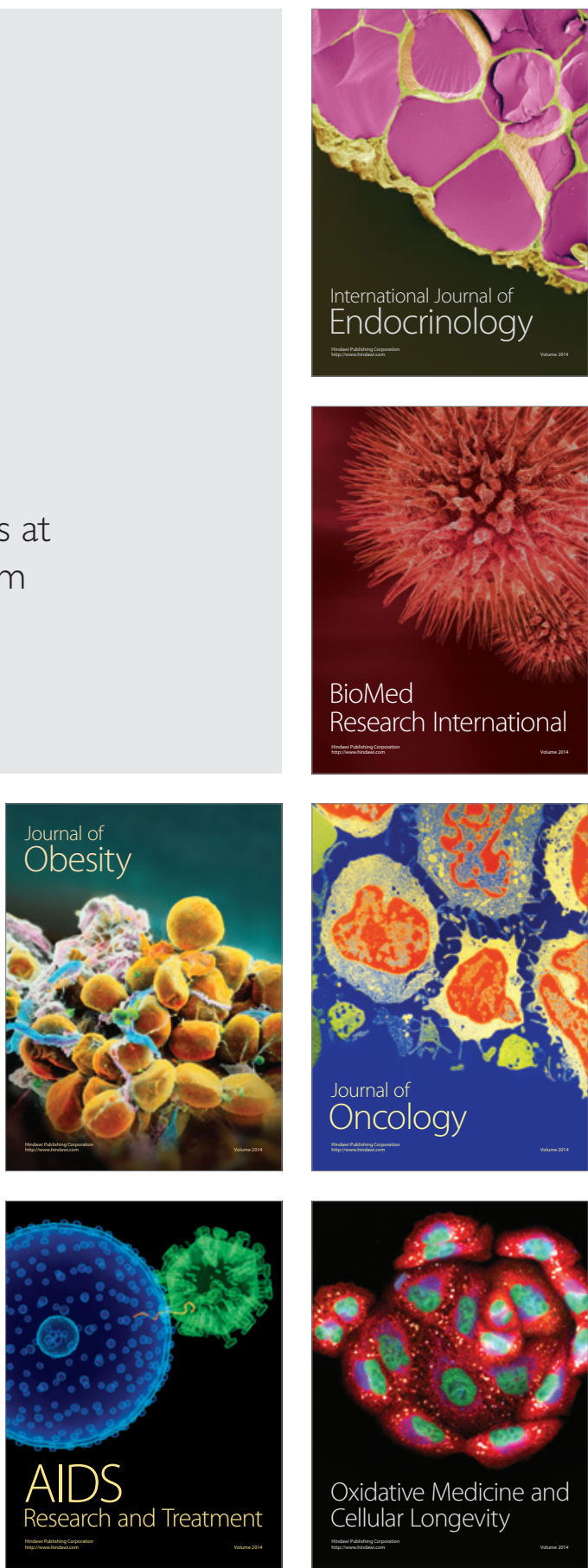